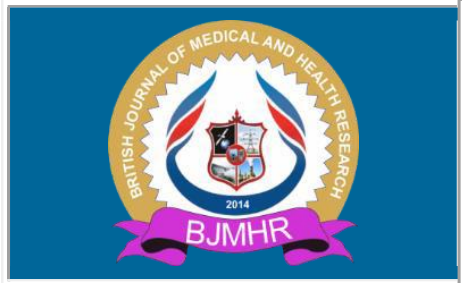

\title{
BJMHR
}

British Journal of Medical and Health Research

Journal home page: www.bjmhr.com

\section{Study In Epidemiology of Cancer In Syrian Arab Republic Between 2008-2012}

1. Kanaan Al-Tameemi ${ }^{1 *}$, Aseel Rashid Abed ${ }^{2}$, Rana Nassour ${ }^{3}$, Aeysha Bakkour ${ }^{4}$

1.Department of Microbiology, Faculty of Medicine, Al-Andalus University for MedicalSciences, Tartous, Syria

2. Pediatric hemato-oncology consultant, Children central teaching hospital, Baghdad,Iraq.

3. Department of Basic Sciences, Faculty of Pharmacy, Al-Andalus University for MedicalSciences, Tartous, Syria.

4. Faculty of Pharmacy, Al-Hawash Private University, Homs, Syria.

\section{ABSTRACT}

The study included an epidemiological survey of cancer cases in the Syrian Arab Republic for the period between 2008-2012. The study was conducted according to international standards established by the International Agency for Research on Cancer (IARC) and the International Association of Cancer Records (IACR). The data were collected and classified according to age, gender, place of incidence and city of residence. Then they were scheduled, graphically illustrated, and statistically analyzed. 46447 new cancer cases were reported during the period of study; 24240 cases among males, 22207 cases among females and 2008 cases between children ( $<15$ years old). The data showed an increase in the new reported cases between 2008 and 2010, and that increment was followed by a decline in the total reported cases until 2012. The survey indicated that breast cancer was the most common type of cancer among females, while lung cancer was the most widespread among males. As for children, the highest incidence rate in the referred period was for leukaemia. Regarding the place of residence, Damascus ranked first in the number of reported case cancers, followed by Aleppo and Rural areas in Damascus.

Keywords: oncology, breast cancer, lung cancer, C.N.S cancer, leukaemia 


\section{INTRODUCTION}

The word cancer is Latin for crab. The condition was termed cancer in ancient times because the swollen blood vessels around an advanced cancer were thought to resemble a crab, with "claws" reaching out into surrounding tissues ${ }^{1}$. Cancer comprises numerous diseases that involve the uncontrolled growth of abnormal cells anywhere in the body. These abnormal cells are termed cancer cells, malignant cells, or tumour cells. Frequently, cancer cells can separatefrom their original location, travel through the blood and lymph systems, and settle in other organs where they can repeat the uncontrolled growth cycle, and that is termed metastatic spread or metastasis ${ }^{2}$.

For a long time, cancer has been considered as an illness caused by mutations and epigenetic alterations that weaken the ability of any cell within the organism to deregulating its proliferation (cell division and cell growth), avoid apoptosis and metastasis, provoking the malignant transformation. Gradually, these early cancer cells produce more daughter cells which accumulate additional mutations and act in coordination to display the full neoplastic phenotype ${ }^{3}$.

Anything that may cause an abnormal cellular development potentially can cause cancer. Somecancer reasons remain unknown while others have environmental or lifestyle triggers or maybe result from more than one known cause. Carcinogenic risk factors can be classified into environmental factors and genetic factors, as the following:

1. The environmental carcinogenic factors include physical factors, chemical factors and biological factors:

- Physical factors: ionized radiation and ultraviolet radiation ${ }^{4,5,6}$.

- Chemical factors: tobacco smoking, alcohol, benzene and its derivatives, nitrogen, nitrites, nitrates, cadmium ${ }^{4,5,7}$.

- Biological factors: many microorganisms may increase the risk of cancer, such as

- Bacteria, like Helicobacter pylori, which can induce the development of gastric cancer 5 .

- Fungi, like Aspergillus flavuns, which produce Aflatoxin B1 that is considered a potent risk factor for liver carcinoma ${ }^{4,5,7,8}$.

- Parasites, like Schistosma haematobium, which is related to bladder cancer ${ }^{5}$.

- Viruses, like T-cell lymphotropic virus (HTLV-1, cause the T cell lemphoma), hepatitis $\mathrm{B}$ and $\mathrm{C}$ viruses (cause hepatocellular carcinoma), human papillomavirus HPV (cause cervical cancer and squamous cell carcinoma) ${ }^{4,5,9}$.

2. The genetic carcinogenic factors are classified into two types; the Oncogenes and the Tumour suppressor genes. Oncogenes are the primary tumour inherited genes. They activate chromosomal translocation or gene amplification, while the Tumour suppressor genes encode proteins, prevent cell transformation, enhance their growth cessation and differentiation and induce programmed cell death. Any abnormality in these genes leads to 
the development of different types of cancer ${ }^{5}$.

As for the International Agency for Research on Cancer (IARC), chemicals are classified into the following categories based on the strength of the causal link for carcinogenicity in humans 10 :

- Group 1: It includes carcinogenic agents to humans.

- Group 2: It is subdivided into:

- Group 2A: Probably carcinogenic to humans

- Group 2B: Possibly carcinogenic to humans

- Group 3: This group is not classifiable as to its carcinogenicity to humans. Agents belonging to this group have unknown carcinogenic potential.

The "cancer stem cell theory" was raised in 1997, and became the new defining model for carcinogenesis. Adult stem cells exist in various body tissues and have an important role in developing, replacing and repairing those tissues. Besides, they show long-term replicative, self-renewal and multi-lineage differentiation potentials. In a healthy body, stem cells properties are tightly regulated; therefore, their alteration may be an essential issue for tumorigenesis ${ }^{3}$. According to this theory, cancer is a stem cell disease. Cancer stem cells generate undifferentiated cells and terminally differentiated ones, similar to normal tissue renewal, but there is a big difference between cancer growth and normal tissue renewal. Usually, normal transit-amplifying cells differentiate and die, at several differentiations, while the cancer transit-amplifying cells can not differentiate normally and instead they undergo maturation arrest, leading to cancer growth ${ }^{3}$.

Cancer is a constant public healthcare issue of modern life that presents a global challenge. According to the latest GLOBOCAN report in 2020, approximately 19.3 million new cancer cases and almost 10.0 million cancer deaths were recorded in $2020{ }^{11}$. This number is more than the global death numbers for AIDS, tuberculosis and malaria combined ${ }^{12}$. Among men, lung, prostate, colorectal, stomach and liver cancer are the most common types of cancer, while breast, colorectal, lung, cervical and thyroid cancer are the most reported amongst women ${ }^{12}$. The cancer burden continues to increase globally, causing enormous physical, emotional and financial strain on individuals, families, communities and health systems. It is expected to reach 28.4 million cases in 2040, a 47\% increment from $2020{ }^{11}$. Many health systems in low- and middle-income countries are not well prepared to handle this burden, and large numbers of cancer patients around the world do not have access to timely quality diagnosis and treatment It is worth noting that survival rates of many types of cancers are improving because of early detection, quality treatment and survivorship care.

\section{MATERIALS AND METHOD}

Our study was based on research and epidemiological investigation of the incidence rates of 
various cancers in the Syrian Arab Republic for the period between 2008-2012. More than 70\% of cancer cases were obtained from the records of Al-Bairouni University Hospital in Damascus, as well as the general hospitals, University hospitals and cancer control department in Damascus.

The cases were confirmed as cancer based on the confirmation of tissue tests in more than $80 \%$ of them, which highly indicate the perfect diagnosis of cancer incidences.

The results were scheduled, based on the international standards set by the International Agency for Research on Cancer (IARC) and the International Association of Cancer Records (IACR) of the World Health Organization (WHO), and statistically analyzed using analysis ofvariance (ANOVA) and Duncan test. The groups were classified based on:

- Age

- Gender

- Place of residence

- Location of incidence

- Age, gender and location relationship with a high or low incidence of each type of cancer.

\section{RESULTS AND DISCUSSION}

The number of cancer cases reported during the period between 2008-2012 was about 46447 new cancer cases (24240 cases (52.2\%) among males, 22207 cases (47.8\%) among females (Table 1 and Figure 1) and 2008 cases (4.3\%) between children under 15 years of age) (Table 2).

The data showed approximately $17.8 \%$ increase in the reported cases in 2010 compared to 2009, and nearly $17.7 \%$ decrease in the reported cases in 2012 compared to 2011.

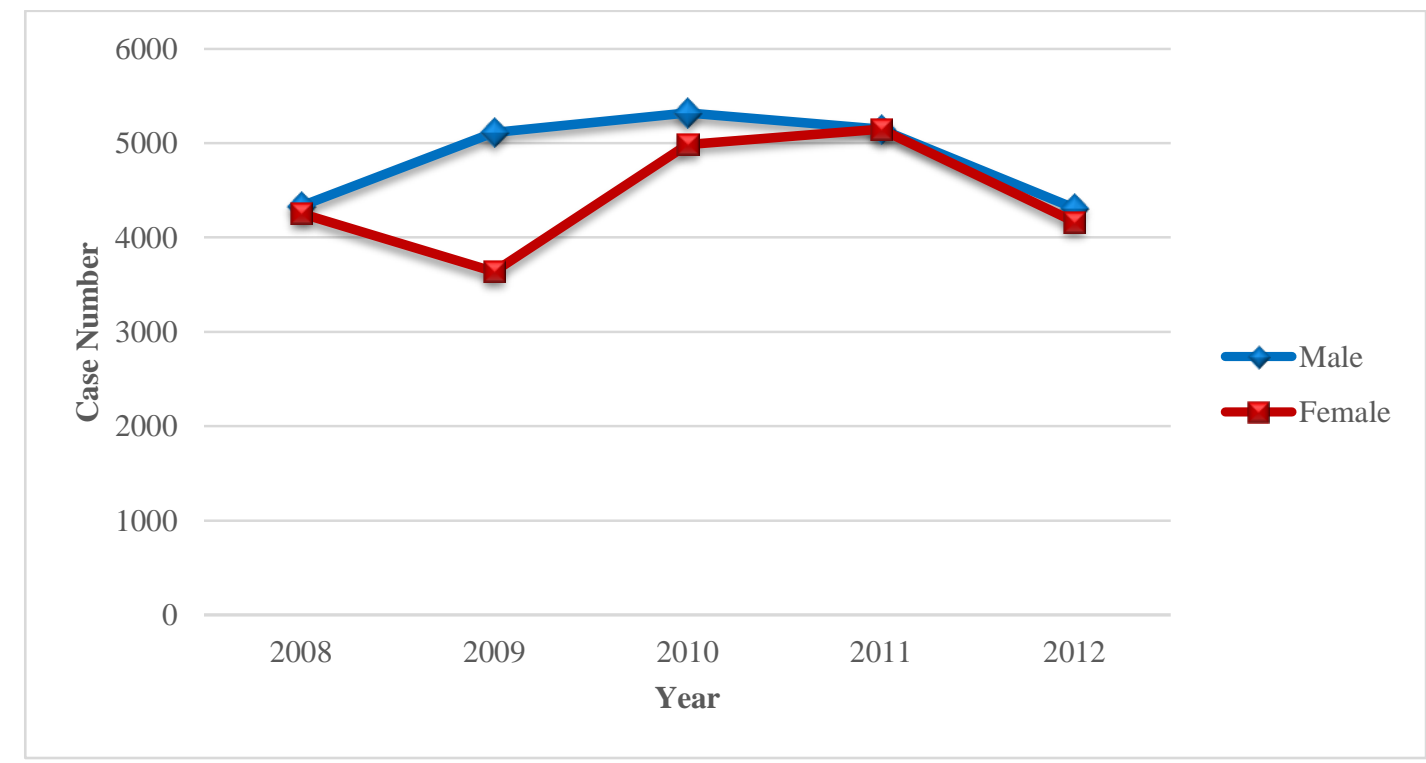

Figure 1: The numerical differences in cancer incidence in Syria in the period between 2008 - 2012 
Table 1: The distribution of cancer cases in Syria for the period between 2008 - 2012, according to gender

\begin{tabular}{cccc}
\hline Year & Male & Female & Total \\
\hline 2008 & 4335 & 4260 & 8595 \\
2009 & 5116 & 3640 & 8756 \\
2010 & 5323 & 4988 & 10311 \\
2011 & 5152 & 5151 & 10303 \\
2012 & 4314 & 4168 & 8482 \\
Sum & 24240 & 22207 & 46447 \\
\hline
\end{tabular}

Table 2: The number of different cancer cases in Syria between 2008-2012 among children under 15 years old, and the incidence rates compared to general cases.

\section{Cancer cases in Syria in 2008}

\begin{tabular}{ccc}
\hline Year & Number of cases & Rate (\%) \\
\hline 2008 & 297 & 3.5 \\
2009 & 355 & 4.1 \\
2010 & 459 & 4.5 \\
2011 & 492 & 4.8 \\
2012 & 405 & 4.8 \\
Sum & 2008 & \\
\hline
\end{tabular}

There were 8595 new cancer cases in 2008; 4335 new cases (50.4\%) among males, 4260 new cases (49.6\%) among females (Table 3), and 297 new cases (3.5\%) among children under 15 years of age.

Lung cancer ranked first among males with $16.5 \%$ of all new cancer cases, while testicular cancer had the lowest incidence rate with $2.3 \%$. Among females, breast cancer ranked first with $35.8 \%$ of newly recorded cases, whereas stomach cancer had the least incidence rate by $1.8 \%$ (Figures 2, 3).

Table 3: The distribution of the most common cancers in Syria, according to their locationand gender in 2008, and the incidence rates compared to total cases

\begin{tabular}{llllll}
\hline Male & \multicolumn{5}{c}{ Female } \\
\hline Location & No. & Rate (\%) & Location & No. & Rate (\%) \\
\hline Lung & 715 & 16.5 & Breast & 1523 & 35.8 \\
Leukaemia & 630 & 14.5 & Leukaemia & 504 & 11.8 \\
Colon & 414 & 9.6 & Thyroid & 429 & 10.1 \\
Bone & 322 & 7.4 & Uterus & 370 & 8.7 \\
C.N.S & 283 & 6.5 & Colon & 311 & 7.3 \\
Bladder & 215 & 5 & C.N.S & 278 & 6.5 \\
Prostate & 188 & 4.3 & Bone & 193 & 4.5 \\
Throat & 165 & 3.8 & Lung & 121 & 2.8 \\
Stomach & 109 & 2.5 & Ovary & 83 & 1.9 \\
Testis & 98 & 2.3 & Stomach & 75 & 1.8 \\
\hline
\end{tabular}




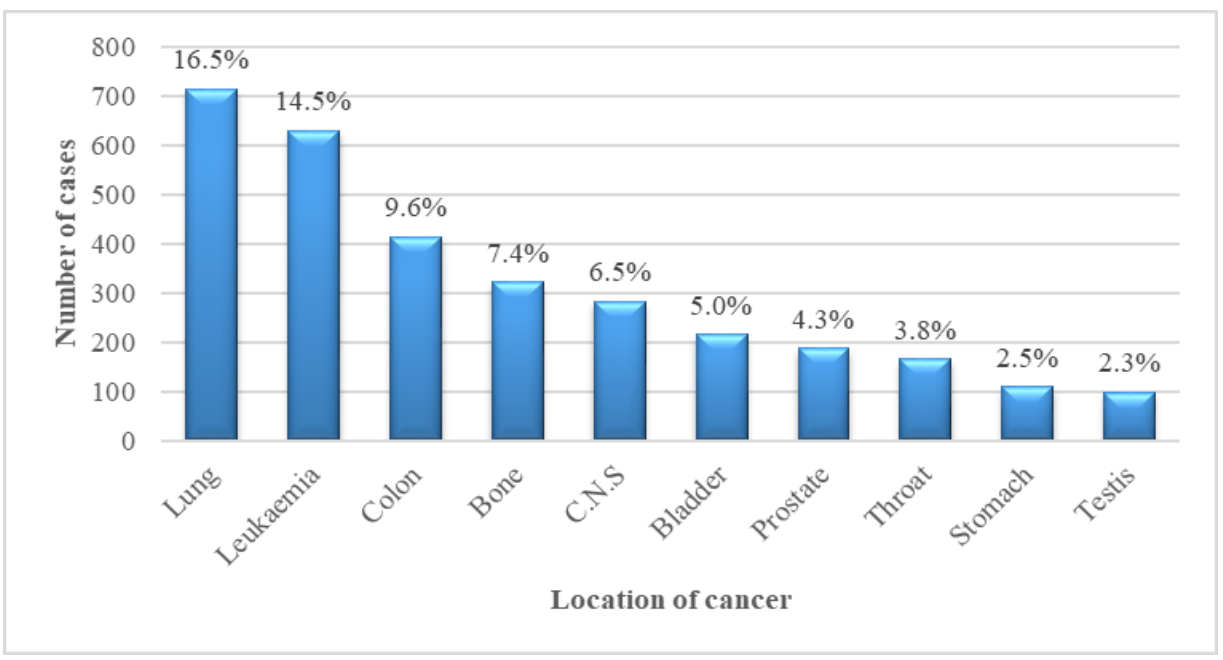

Figure 2: The most distributed cancers among males in Syria, according to their location in 2008

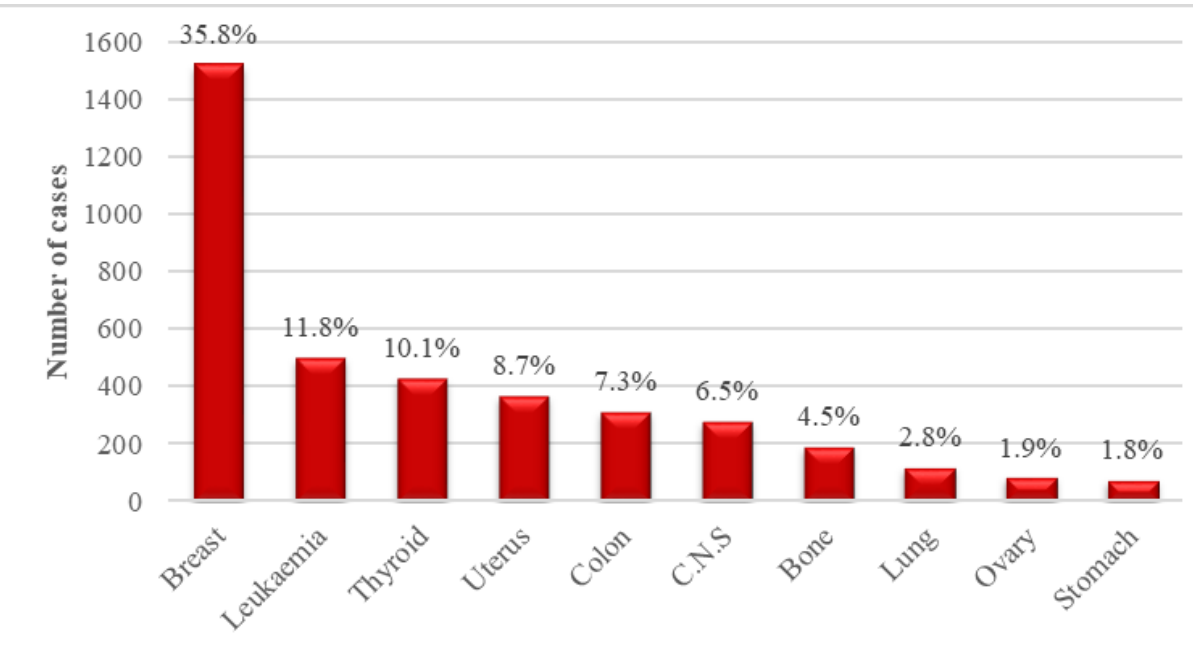

Location of cancer

Figure 3: The most distributed cancers among females in Syria, according to their location in 2008

Leukaemia in children under 15 years of age ranked first reaching $38.7 \%$ of total cancer cases, while urinary system cancer recorded the lowest rate with $6.4 \%$ of the total cases (Table 4 , Figure 4). 


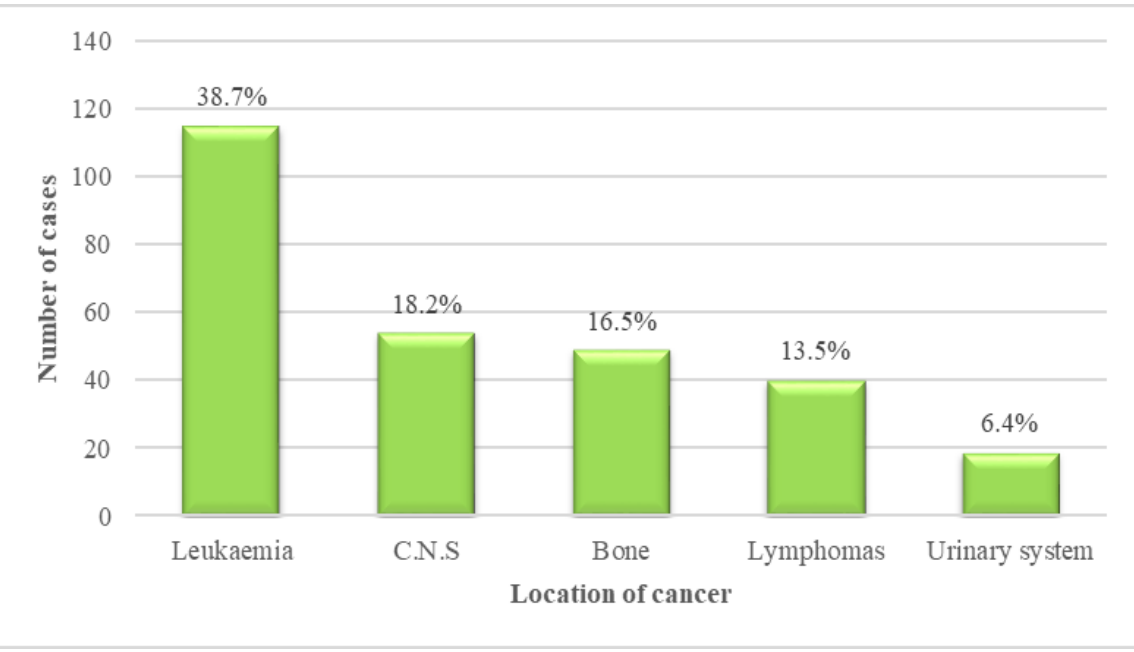

Figure 4: The most distributed cancers (and their percentages) among children $(<15$ years) in Syria in 2008

Table 4: The most common cancer cases (and their percentages) among children $(<15$ years) in Syria in 2008

\begin{tabular}{lll}
\hline Location & Number of cases & Rate $(\boldsymbol{\%})$ \\
\hline Leukaemia & 115 & 38.7 \\
C.N.S & 54 & 18.2 \\
Bone & 49 & 16.5 \\
Lymphomas & 40 & 13.5 \\
Urinary system & 19 & 6.4 \\
\cline { 1 - 1 }
\end{tabular}

\section{Cancer cases in Syria in 2009}

There were 8756 new cancer cases in 2009: 5116 cases (58.4\%) among males, 3640 cases (41.6\%) among females (Table 5), and 355 cases (4.1\%) among children under the age of 15. Lung cancer ranked first among males (12.6\% of new reported cases), while testicular cancer ranked last (2.3\%) (Figure 5). As for females, the highest incidence rate was for breast cancer(40.7\%) and the lowest for stomach cancer $(1.1 \%)$ (Figure 6).

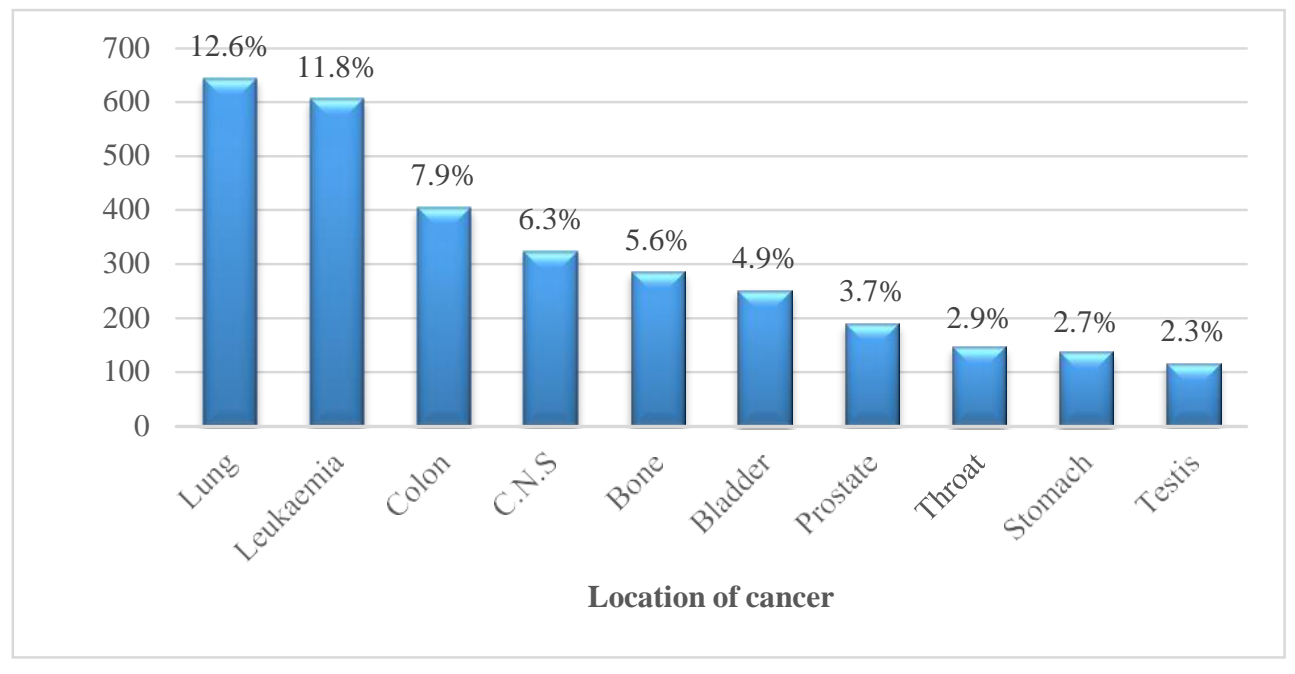

Figure 5: The most distributed cancers among males in Syria, according to their location in 2009 


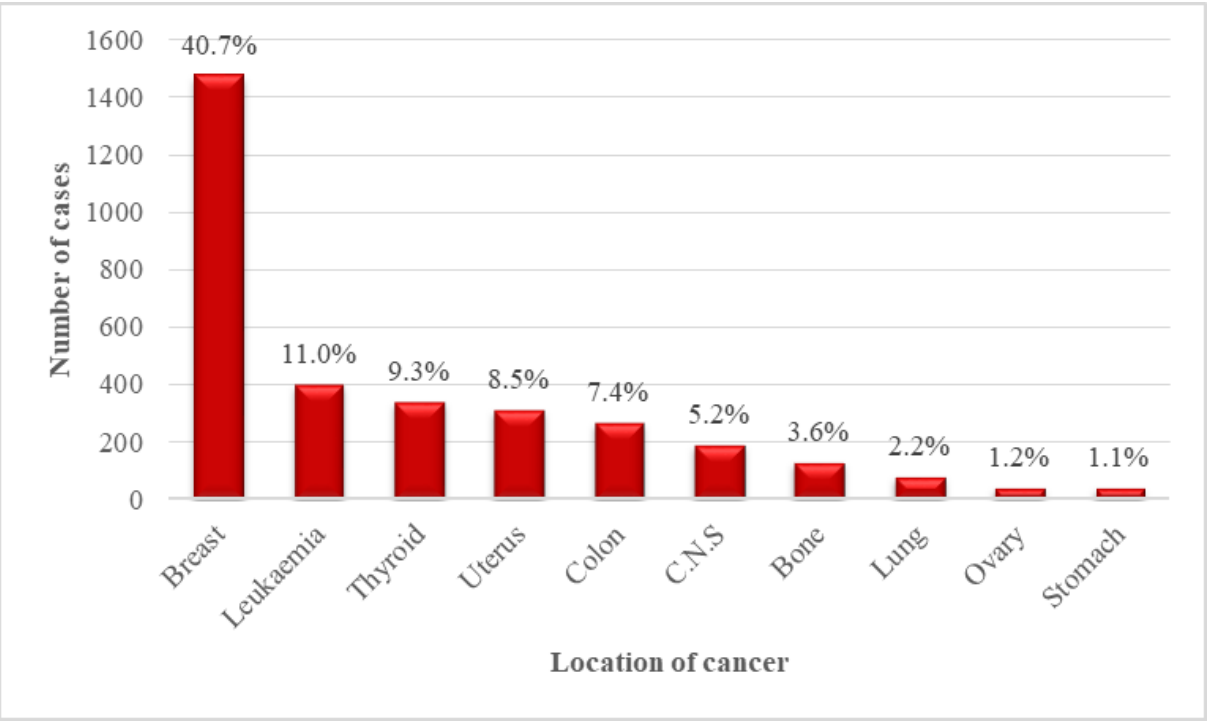

Figure 6: The most distributed cancers among females in Syria, according to their location in 2009

Table 5: The distribution of the most common cancers (and their percentages) in Syria, according to their location and gender in 9002

\begin{tabular}{|c|c|c|c|c|c|}
\hline $\begin{array}{l}\text { Male } \\
\text { Location }\end{array}$ & No. & Rate $(\%)$ & $\begin{array}{l}\text { Female } \\
\text { Location }\end{array}$ & No. & Rate $(\%)$ \\
\hline Lung & 644 & 12.6 & Breast & 1480 & 40.7 \\
\hline Leukaemia & 606 & 11.8 & Leukaemia & 400 & 11 \\
\hline Colon & 405 & 7.9 & Thyroid & 340 & 9.3 \\
\hline C.N.S & 324 & 6.3 & Uterus & 311 & 8.5 \\
\hline Bone & 286 & 5.6 & Colon & 270 & 7.4 \\
\hline Bladder & 252 & 4.9 & C.N.S & 190 & 5.2 \\
\hline Prostate & 190 & 3.7 & Bone & 130 & 3.6 \\
\hline Throat & 148 & 2.9 & Lung & 80 & 2.2 \\
\hline Stomach & 138 & 2.7 & Ovary & 43 & 1.2 \\
\hline Testis & 116 & 2.3 & Stomach & 40 & 1.1 \\
\hline
\end{tabular}

Leukaemia was the most common cancer (35.5\%) among children ( $<15$ years) while urinary system cancer was the least common (6.5\%) (Table 6, Figure 7).

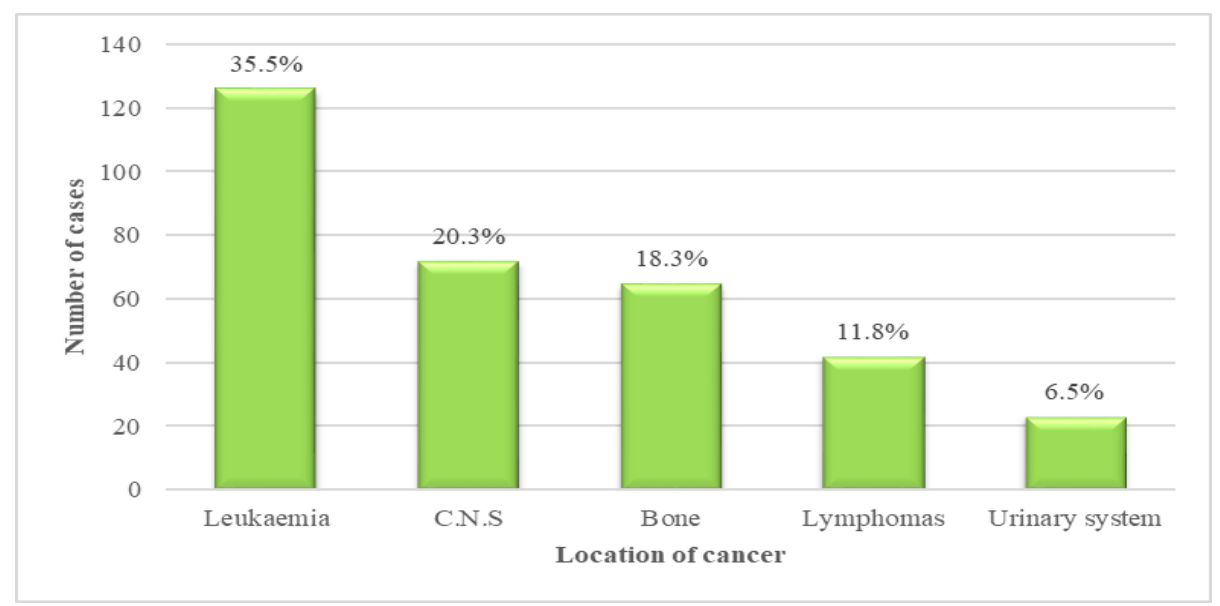

Figure 7: The most distributed cancers (and their percentages) among children $(<15$ years) in Syria in 2009 
Table 6: The number of different cancer cases (and their percentages) among children $(<15$ years) in Syria in 2009

\section{Cancer cases in Syria in 2010}

\begin{tabular}{lll}
\hline Location & Number of cases & Rate (\%) \\
\hline Leukaemia & 126 & 35.5 \\
C.N.S & 72 & 20.3 \\
Bone & 65 & 18.3 \\
Lymphomas & 42 & 11.8 \\
Urinary system & 23 & 6.5 \\
\hline
\end{tabular}

There were 10311 new cancer cases in 2010: 5323 cases (51.6\%) among males, 4988 cases (48.4\%) among females (Table 7) and 459 cases (4.5\%) among children (<15 years).

Table 7: The distribution of the most common cancers (and their percentages) in Syria, according to their location and gender in 2010

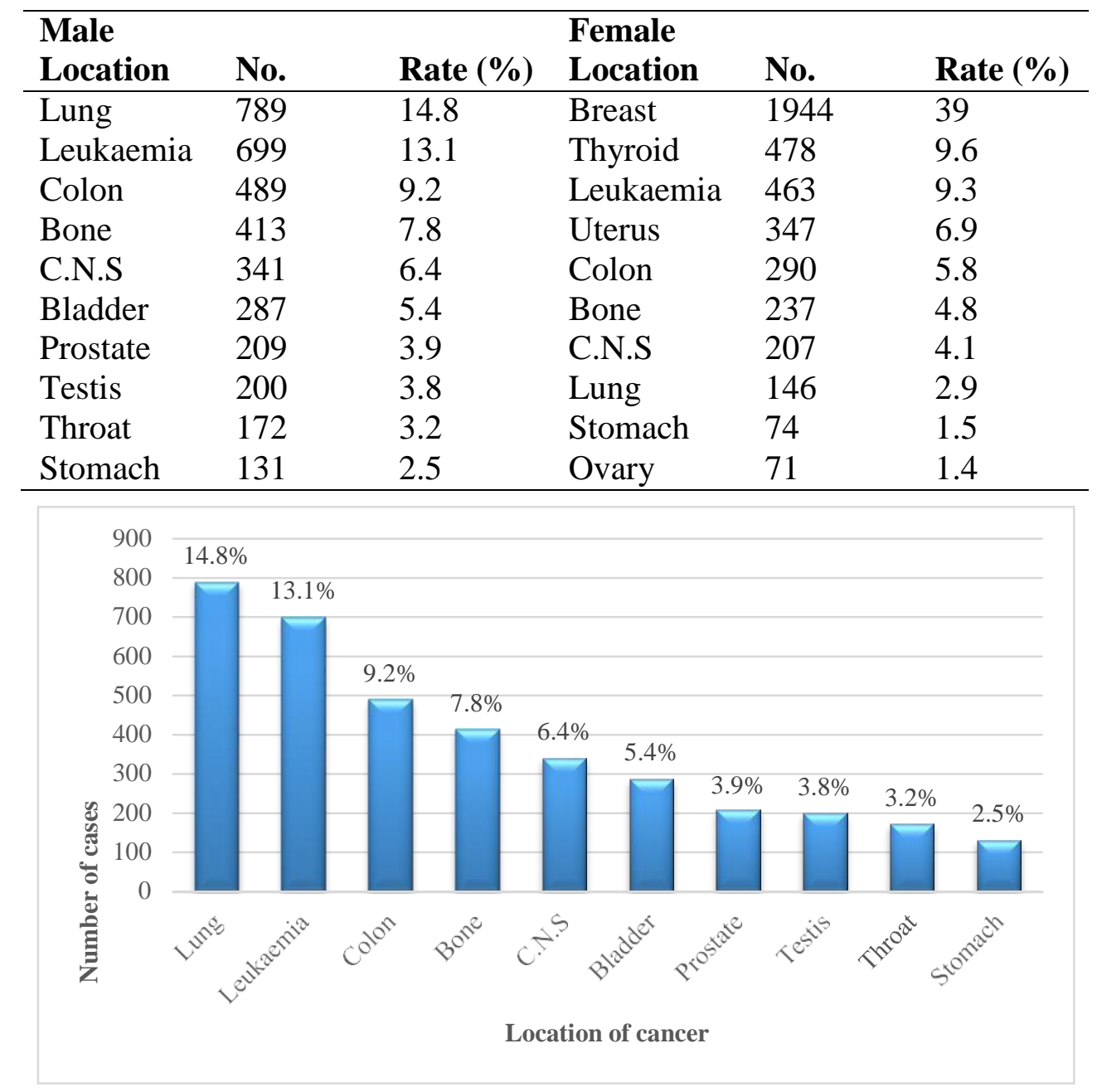

Figure 8: The most distributed cancers among males in Syria, according to their location in 2010

Lung cancer ranked first among males (14.8\% of newly reported cases), while stomach cancer ranked last (2.5\%) (Figure 8). Meanwhile, breast cancer had the highest incidence rate (39\%) and ovary cancer recorded the lowest ones (1.4\%) among females (Figure 9). 


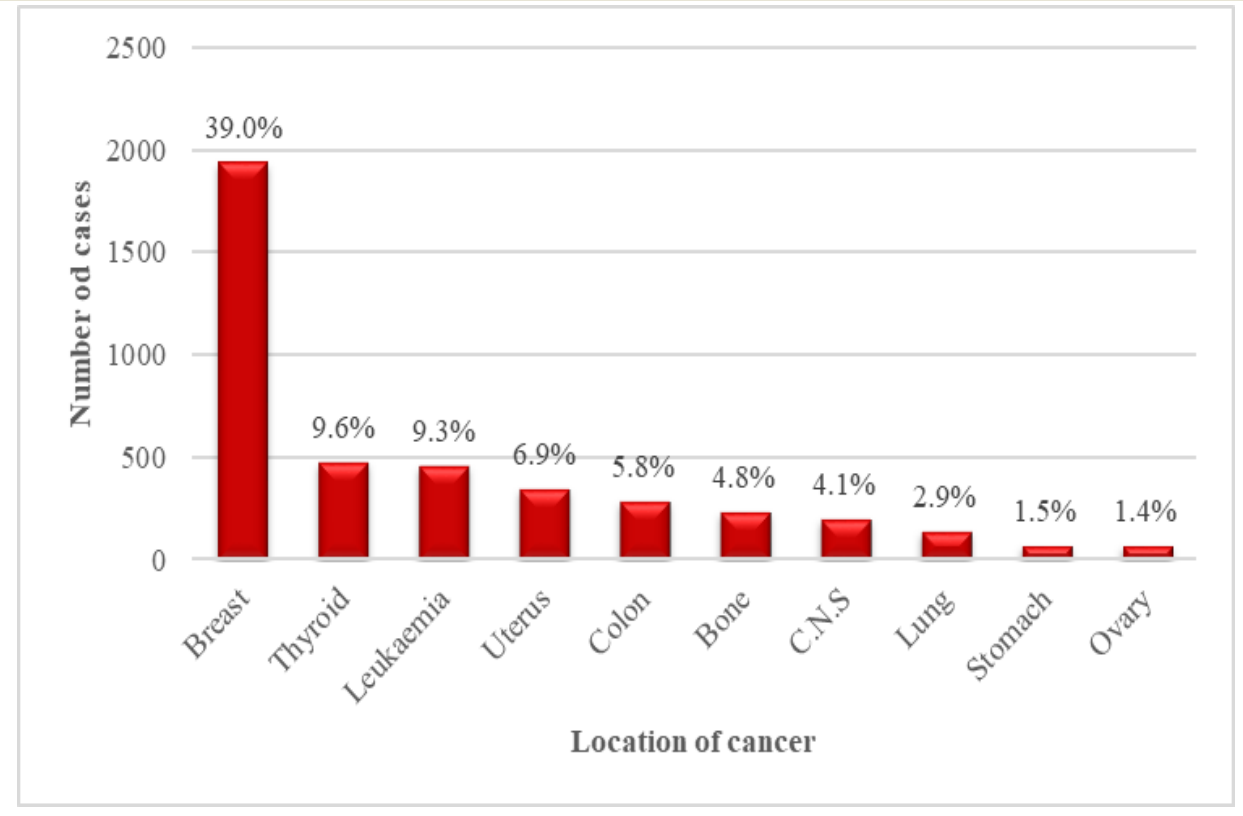

Figure 9: The most distributed cancers among females in Syria, according to their location in 2010

Table 8: The number of different cancer cases (and their percentages) among children ( $<15$ years) in Syria in 2010

\begin{tabular}{lll}
\hline Location & Number of cases & Rate (\%) \\
\hline Leukaemia & 209 & 45.5 \\
Lymphomas & 81 & 17.6 \\
Bone & 54 & 11.8 \\
C.N.S & 41 & 8.9 \\
Urinary system & 21 & 4.6 \\
\hline
\end{tabular}

Table 9: The distribution of the most common cancers (and their percentages) in Syria, according to their location and gender in 2011

\begin{tabular}{llllll}
\hline $\begin{array}{l}\text { Male } \\
\text { Location }\end{array}$ & No. & Rate $(\boldsymbol{\%})$ & $\begin{array}{l}\text { Female } \\
\text { Location }\end{array}$ & No. & Rate $(\boldsymbol{\%})$ \\
\hline Lung & 778 & 15.1 & Breast & 1988 & 38.6 \\
Leukaemia & 726 & 14.1 & Leukaemia & 447 & 8.7 \\
Colon & 446 & 8.7 & Thyroid & 430 & 8.3 \\
Bone & 390 & 7.6 & Uterus & 399 & 7.7 \\
C.N.S & 373 & 7.2 & Colon & 356 & 6.9 \\
$\quad$ Bladder & 352 & 6.8 & Bone & 236 & 4.6 \\
$\quad$ Prostate & 296 & 5.7 & C.N.S & 214 & 4.2 \\
$\quad$ Throat & 206 & 4 & Lung & 170 & 3.3 \\
Testis & 135 & 2.6 & Ovary & 63 & 1.22 \\
Stomach & 89 & 1.7 & Stomach & 62 & 1.2 \\
\hline
\end{tabular}

Table 10: The number of different cancer cases (and their percentages) among children ( $<15$ years) in Syria in 2011

\begin{tabular}{lll}
\hline Location & Number of cases & Rate (\%) \\
\hline Leukaemia & 195 & 39.6 \\
C.N.S & 74 & 15 \\
Bone & 61 & 12.4 \\
Lymphomas & 59 & 12 \\
Urinary system & 25 & 5.1 \\
\cline { 2 - 3 } & &
\end{tabular}


Just like in 2008 and 2009, leukaemia had the highest incidence rate (45.5\%) among children $(<15$ years) and urinary system cancer had the lowest incidence rates $(4.6 \%)$ (Table 8 , Figure 10).

\section{Cancer casesin Syria in 2011}

There were 10303 new cancer cases in 2011: 5152 cases (50\%) among males, 5151 cases (50\%) among females (Table 9), and 492 cases (4.8\%) among children ( $<15$ years). Lung cancer ranked first among males (15.1\% of newly reported cases), while stomach cancer ranked the last (1.7\%) (Figure 11). On the other hand, breast cancer had the highest occurrence rate (38.6\%) and stomach cancer recorded the lowest ones (1.2\%) among females (Figure 12). As for children ( $<15$ years), leukaemia had the highest incidence rate $(39.6 \%)$ and urinary system cancer had the lowest incidence rate (5.1\%) (Table 10, Figure 13).

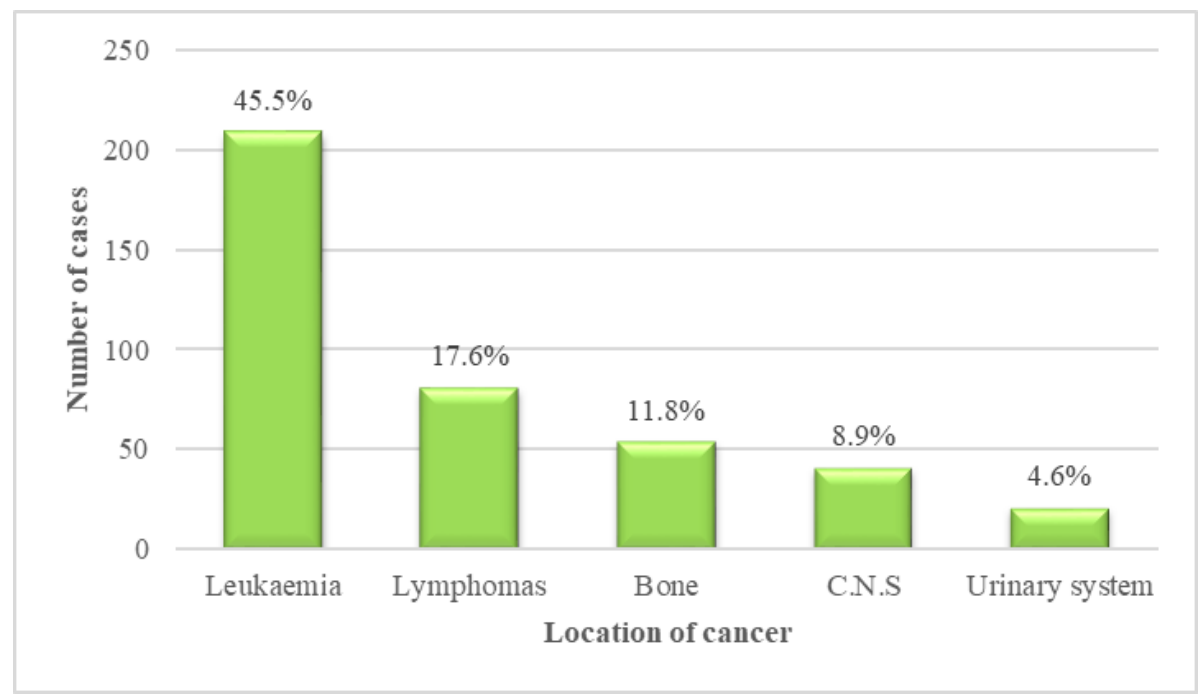

Figure 10: The most distributed cancers (and their percentages) among children $(<15$ years) in Syria in 2010

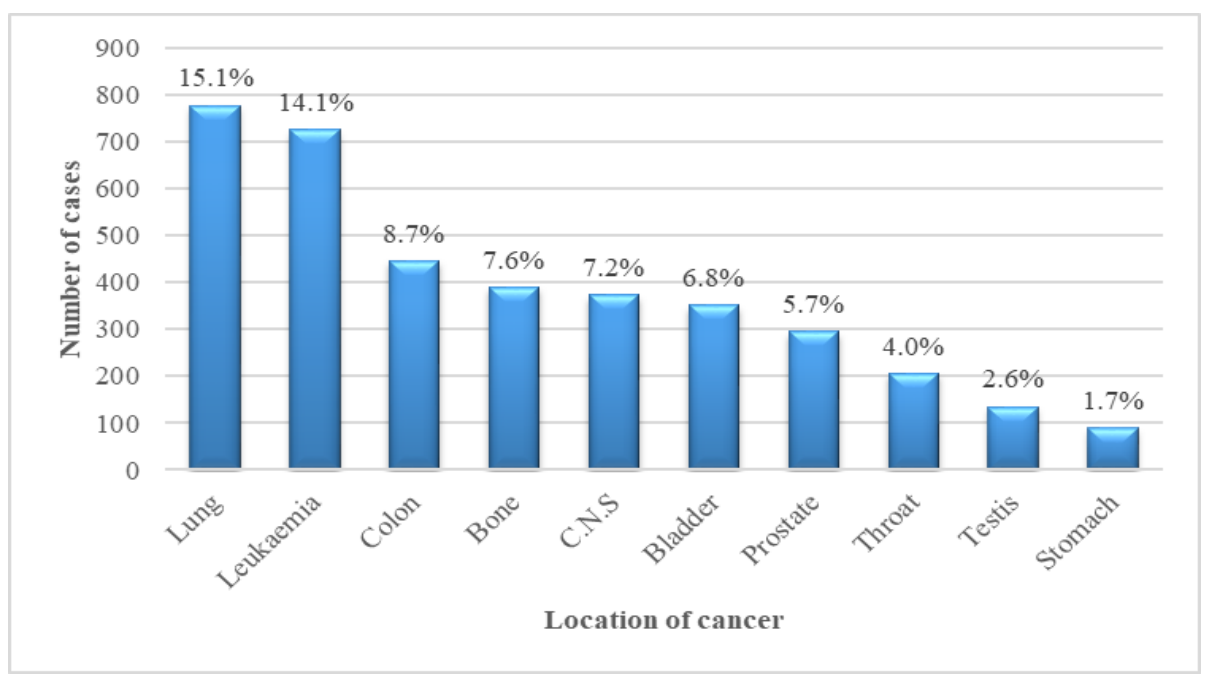

Figure 11: The most distributed cancers among males in Syria, according to their location in 2011 


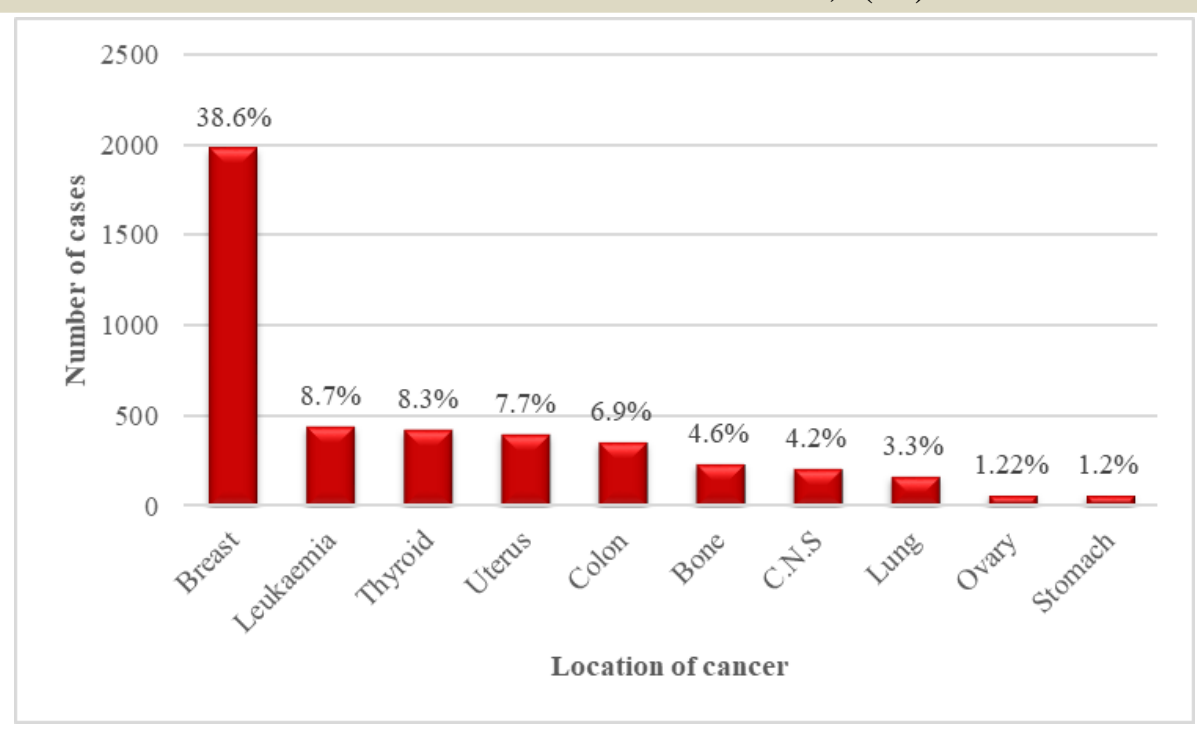

Figure 12: The most distributed cancers among females in Syria, according to their location in 2011

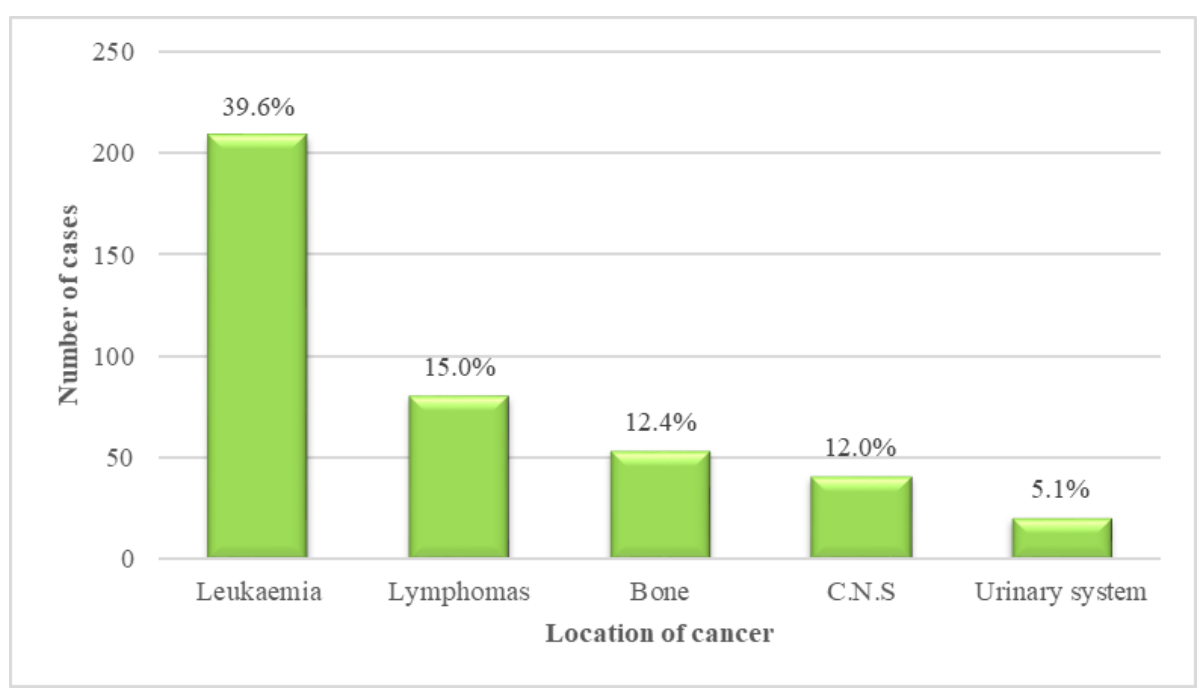

Figure 13.: The most distributed cancers (and their percentages) among children (<15years) in Syria in 2011

\section{Cancer cases in Syria in 2012}

There were 8482 new cancer cases in 2012 in Syria: 4314 cases (50.9\%) among males, 4168 cases (49.1\%) among females (Table 11), and 405 cases (4.8\%) among children (<15 years). Just like in 2011, lung cancer had the highest cancer rates among males (14.9\% of newly reported cases), while stomach cancer had the lowest ones (2.3\%) (Figure 14). While among females, breast cancer had the highest occurrence rates (34.4\%) and stomach cancer recorded the lowest ones (1.4\%) (Figure 15).

Table 11: The distribution of the most common cancers (and their percentages) in Syria according to their location and gender in 2012

\begin{tabular}{llllll}
\hline Male & & & Female & \\
Location & No. & Rate (\%) & Location & No. & Rate (\%) \\
\hline Lung & 643 & 14.9 & Breast & 1432 & 34.4 \\
Leukaemia & 626 & 14.5 & Leukaemia & 430 & 10.3
\end{tabular}




$\begin{array}{llllll}\text { Colon } & 492 & 11.4 & \text { Uterus } & 390 & 9.4 \\ \text { C.N.S } & 303 & 7 & \text { Colon } & 320 & 7.7 \\ \text { Bone } & 284 & 6.6 & \text { Thyroid } & 300 & 7.2 \\ \text { Testis } & 231 & 5.4 & \text { Bone } & 199 & 4.8 \\ \text { Bladder } & 219 & 5.1 & \text { C.N.S } & 164 & 3.9 \\ \text { Throat } & 169 & 3.9 & \text { Lung } & 126 & 3 \\ \text { Prostate } & 147 & 3.4 & \text { Ovary } & 65 & 1.6 \\ \text { Stomach } & 98 & 2.3 & \text { Stomach } & 59 & 1.4\end{array}$

Table 12: The number of different cancer cases (and their percentages) among children $(<15$ years) in Syria in 2012

\begin{tabular}{lll}
\hline Location & Number of cases & Rate (\%) \\
\hline Leukaemia & 139 & 34.3 \\
Lymphomas & 65 & 16 \\
Bone & 60 & 14.8 \\
C.N.S & 57 & 14.1 \\
Urinary system & 26 & 6.4 \\
& &
\end{tabular}

As for children (<15 years), leukemia had the highest incidence rate $(34.3 \%)$ and urinary system cancer had the lowest incidence rates (6.4\%) (Table 12, Figure 16).

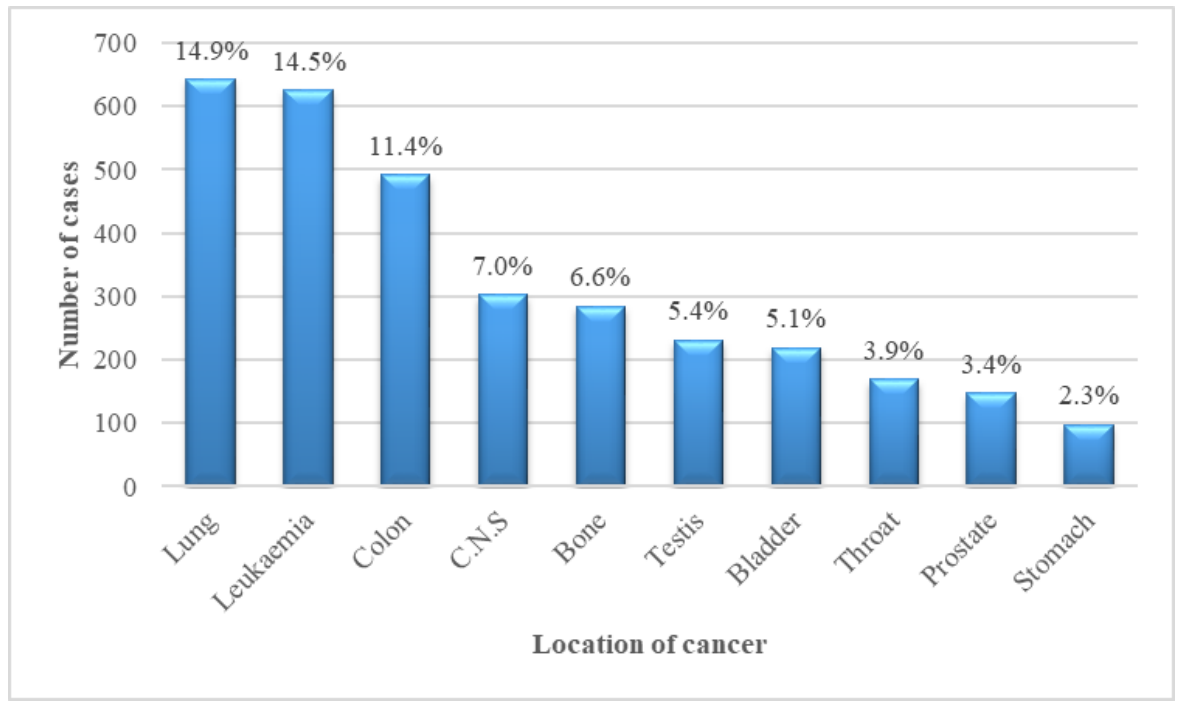

Figure 14: The most distributed cancers among males in Syria, according to their location in 2012

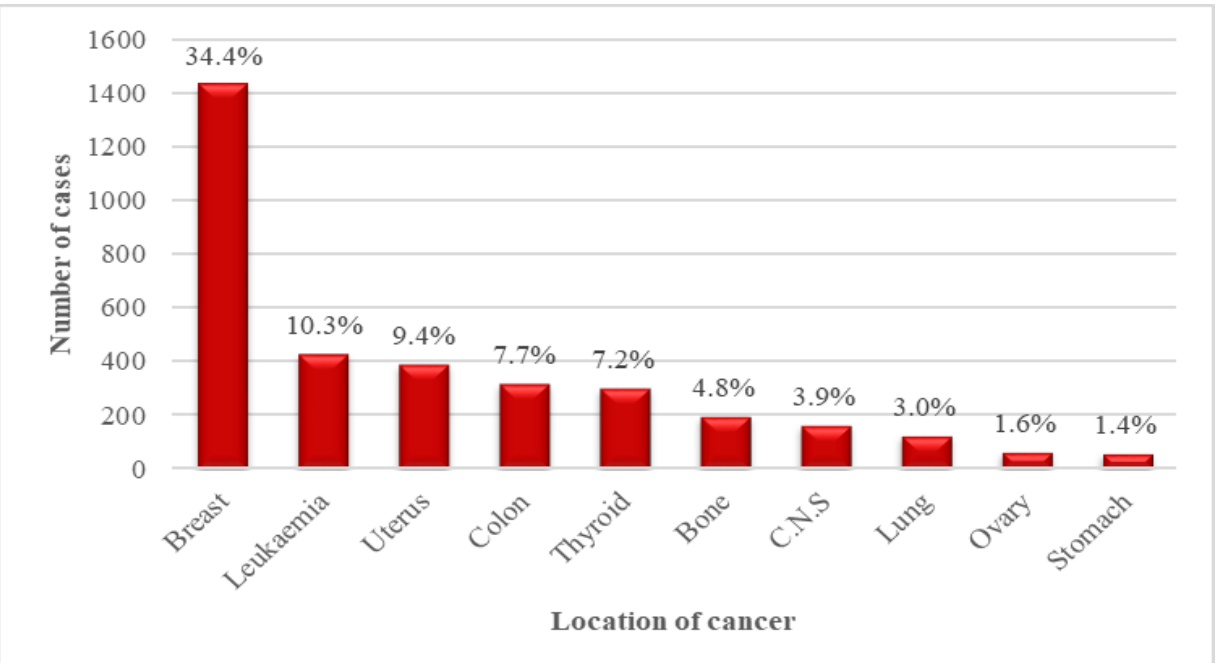

Figure 15: The most distributed cancers among female in Syria, according to their 


\section{location in 2012}

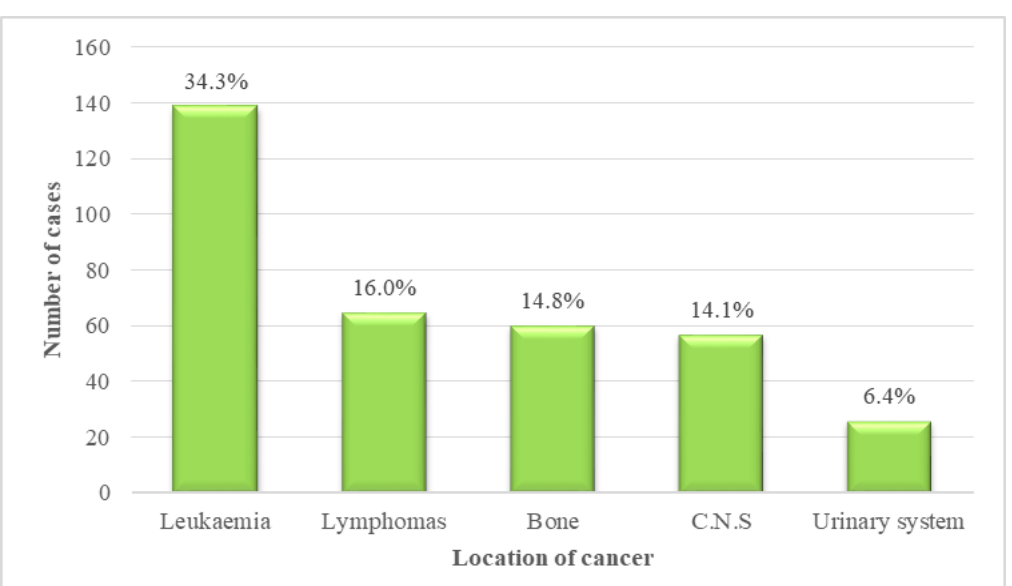

Figure 16: The most distributed cancers (and their percentages) among children $(<15$ years) in Syria in 2012

Table 13: New cancer cases reported at Al-Bairouni Hospital by governorates between 2008-2012

\begin{tabular}{|c|c|c|c|c|c|}
\hline & Year & & & & \\
\hline Governorate & 2008 & 2009 & 2010 & 2011 & 2012 \\
\hline Damascus & 1132 & 1259 & 1417 & 1552 & 1222 \\
\hline Rural Damascus & 968 & 1038 & 1079 & 1120 & 982 \\
\hline Daraa & 465 & 477 & 527 & 509 & 414 \\
\hline Al-Sweida & 330 & 280 & 356 & 381 & 321 \\
\hline Quneitra & 256 & 198 & 302 & 299 & 276 \\
\hline Homs & 998 & 758 & 970 & 887 & 1019 \\
\hline Hama & 786 & 759 & 968 & 921 & 760 \\
\hline Tartous & 270 & 440 & 435 & 443 & 228 \\
\hline Lattakia & 225 & 436 & 507 & 481 & 240 \\
\hline Aleppo & 1202 & 1144 & 1452 & 1346 & 983 \\
\hline Idleb & 441 & 509 & 632 & 609 & 477 \\
\hline Al-Raqqa & 333 & 346 & 393 & 398 & 347 \\
\hline Deir-ezzor & 573 & 502 & 558 & 582 & 560 \\
\hline Al-Hasakeh & 616 & 610 & 715 & 775 & 653 \\
\hline Sum & 8595 & 8756 & 10311 & 10303 & 8482 \\
\hline
\end{tabular}

Table 14: The distribution of cancer cases in the Syrian governorates, according to gender

\begin{tabular}{lllllllllll}
\hline & $\mathbf{9 0 0 2}$ & & $\mathbf{2 0 0 9}$ & & $\mathbf{2 0 1 0}$ & & $\mathbf{2 0 1 1}$ & & $\mathbf{2 0 1 2}$ \\
Governorate & Male & Female & Male & Female & Male & Female & Male & Female & Male & Female \\
\hline Damascus & 589 & 543 & 699 & 560 & 682 & 735 & 717 & 835 & 592 & 630 \\
Rural & 477 & 491 & 623 & 415 & 531 & 548 & 550 & 570 & 492 & 490 \\
Damascus & & & & & & & & & & \\
Daraa & 223 & 242 & 269 & 208 & 275 & 252 & 254 & 255 & 226 & 188 \\
Al-Sweida & 156 & 174 & 173 & 107 & 178 & 178 & 175 & 206 & 135 & 186 \\
Quneitra & 140 & 116 & 108 & 90 & 156 & 146 & 141 & 158 & 135 & 141 \\
Homs & 515 & 483 & 430 & 328 & 500 & 470 & 440 & 447 & 506 & 513 \\
Hama & 428 & 358 & 441 & 318 & 512 & 456 & 481 & 440 & 403 & 357 \\
Tartous & 139 & 131 & 253 & 187 & 229 & 206 & 220 & 223 & 116 & 112 \\
Lattakia & 105 & 120 & 226 & 210 & 234 & 273 & 224 & 257 & 108 & 132 \\
Aleppo & 584 & 618 & 698 & 446 & 773 & 679 & 664 & 682 & 510 & 473 \\
Idleb & 202 & 239 & 308 & 201 & 365 & 267 & 339 & 270 & 245 & 232 \\
Al-Raqqa & 150 & 183 & 207 & 139 & 223 & 170 & 216 & 182 & 197 & 150
\end{tabular}




\begin{tabular}{lllllllllll} 
Kanaan et. & & \multicolumn{4}{c}{ Br J Med Health Res. 2021;8(07) } & \multicolumn{3}{c}{ ISSN: 2394-2967 } \\
Deir-ezzor & 277 & 296 & 292 & 210 & 290 & 268 & 318 & 264 & 304 & 256 \\
Al-Hasakeh & 350 & 266 & 389 & 221 & 375 & 340 & 413 & 362 & 345 & 308 \\
Sum & 4335 & 4260 & 5116 & 3640 & 5323 & 4988 & 5152 & 5151 & 4314 & 4168 \\
\hline
\end{tabular}

Table 15: The number of cancer cases in Syria, according to smoking

\begin{tabular}{lccccc}
\hline & \multicolumn{5}{c}{ Year } \\
& 2008 & 2009 & 2010 & 2011 & 2012 \\
\hline Smoker & 1595 & 1566 & 1367 & 1625 & 1165 \\
Non-smoker & 6475 & 6798 & 8485 & 8180 & 7043 \\
Previously smoker & 525 & 392 & 459 & 498 & 274 \\
Sum & $\underline{8595}$ & $\underline{8756}$ & $\underline{10311}$ & $\underline{10303}$ & $\underline{8482}$ \\
\hline
\end{tabular}

\section{Geographical distribution of cancer cases in Syria according to governorates}

Our survey of cancer incidence rates, which was reported at Al-Bairouni Hospital between 2008 - 2012 and classified according to the governorates revealed the geographical differences between the numbers of incidence (Tables 13, 14).

Concerning the number of cancer cases, Damascus ranked first (14.2\%), followed by Aleppo (13.2\%) and Rural areas in Damascus (11.2\%).

\section{Smoking and cancer ratios in Syria from 2008 to 2012}

Tobacco smoke contains thousands of inorganic and organic chemicals. Most of the compounds in tobacco smoke are products of pyrolysis and pyrosynthesis formed during burning or smouldering of the tobacco (tar). The rest of them already exist in the tobacco leaf and is transferred without any change into the tobacco smoke ${ }^{13}$.

Of this massive number of compounds, at least 60 have carcinogenic activity in humans, and many more are suspected carcinogens ${ }^{14}$. The most known of these are the polycyclic aromatic hydrocarbons (such as benzo(a)pyrene), N-nitrosamines, aromatic amines, heterocyclic amines, toxic metals (like arsenic, cadmium, chromium, lead, selenium, beryllium, copper, radioactive polonium-210) and alkaloids (cotinine and nicotine) ${ }^{13}, 15,16$. Even smokeless tobacco products, despite the fact that they are not burned, include substantial levels of toxic chemicals, mainly the $\mathrm{N}$-nitrosamines ${ }^{16}$.

Approximately $30 \%$ of cancer deaths are attributed to smoking ${ }^{17}$. The main effects of these compounds are ranging from reversible disorders in cell functions and the immune system to irreversible modifications in growth control ${ }^{13}$. Besides their genotoxic effects, since some of them attack the $\mathrm{O}^{6}$-position of guanine in the DNA of the larynx, bronchi, and lung epithelial cells ${ }^{14,18}$. All those effects can eventually cause cardiovascular failure, lung disease, DNA defects and cancer ${ }^{13}$.

Table 15 shows the numbers of cancer cases in Syria according to smoking, based on the statistics of Al-Bairouni Hospital.

\section{DISCUSSION}

The overall incidence of cancer in the Syrian governorates during the period 2008-2012 ranged 
between 63 and 75 new cancer cases per 100,000 citizens, which is an acceptable rate, since it is expected to have more than 100 cases per 100000 individuals according to the World Health Organization and the International Agency for Cancer Research. It could be understood because not all the new cases are reported by pathologists and some private hospitals and clinics.

During the period of study, the average numbers of cancer cases was 4848 (standard deviation= 484) among males, 4441 (standard deviation= 623) among females and 402 (standard deviation $=78$ ) among children.

To compare the average numbers of different types of cancer during the years of study, ANOVA and Duncan tests were performed. ANOVA test indicated to significant differences statistically $(\mathrm{P}$-value $<0.05)$ between the average numbers of different cancers during the years of study. Duncan test implied that Lung cancer and Leukaemia ranked first among males (they differed significantly from the other types of cancer, but with no significant difference compared to each other). While among females, breast cancer ranked first and had significant differences with other types of cancer. Concerning children, Leukaemia had the highest average and was significantly different from the rest of cancer incidences.

Given the number of new cancer cases in the Syrian governorates during the studied years, Damascus ranked first with 6582 cases (14.2\%), followed by Aleppo with 6127 cases (13.2\%), then Rural areas in Damascus with 5187 cases (11.2\%). Statistically, Damascus and Aleppo didn't differ in comparison to each other, but they differed significantly compared to other governorates. The data showed that only about $20 \%$ of the cases were diagnosed in the early stages. It`s worth noting that ANOVA test referred to significant differences among governorates according to gender between 2008-2012.

Our data implied that the highest number of cancer cases were recorded in 2010 and 2011 ( $22.20 \%$ and $22.18 \%$ of all cases in the studied period respectively). In general, we notice an increase in the number of cancer cases until 2010 and a later decline in new cancer cased in 2011 and 2012, and this may be due to:

1. The development of clinical and laboratory diagnostic methods with an increase in the diagnostic expertise of the medical staff.

2. The high percentage of pollutants resulting from the increased number of factories and cars.

3. The increased population, which leads to a rise in the number of vulnerable cases, whether for genetic or environmental reasons.

4. Lack of legislations and procedures concerning the limitation of environmental pollution and determining regions for establishing the highly negative environmental impact of industries. 
As for the most common cancers in the Syrian Arab Republic, they were:

\section{Breast cancer}

Breast cancer is the most commonly diagnosed cancer and a leading cause of death among women. It ranked first among Syrians, with 8367 new cases during the five years of study and $18 \%$ of the total number of reported cancer cases. It was the most common type of cancer among females (37.7\% of all cancer cases).

Despite the risk increment of breast cancer with age, there is a marked decline in this rate after losing the ovarian function (due to a bilateral loophorectomy or menopause). This refers to the fact that hormone production by the ovaries (namely oestrogen) represents a crucial risk factor for breast cancer ${ }^{19,20,21}$. On the other hand, the prolonged exposure to oestrogen is closely linked to breast cancer risk, therefore breast cancer is quite uncommon in Turner syndrome (because these women rarely ovulate) ${ }^{19,22,23}$. Generally, a 1-year delay in the menarche onset reduces the risk for breast cancer development later in life by $5 \%$, and each 1 -year delay in the menopause onset increases this risk by $3 \%$ 19, 22, 24, 25, 26 .

Breastfeeding is associated with a slight decrease in the risk for breast cancer ${ }^{19,25}$. Nowadays, breastfeeding began to decline and a lot of women prefer to feed their children artificially using nursing bottles. It is noteworthy that studies revealed that breastfeeding reduces not only breast cancer risk but endometrial and ovarian cancers risk as well ${ }^{27}$. This effect might be due to the delay of ovulation resumption during breastfeeding ${ }^{19,28}$, changing the cells in the breast so they might be more resistant to alterations that lead to cancer.

Moreover, genetic predisposition is responsible for $5-10 \%$ of all breast cancer cases ${ }^{25,29}$, especially since consanguineous marriage represents a social norm in the east including Syria, and this, in turn, cannot be overlooked in the occurrence of cancers generally. Having a firstdegree relative with breast cancer almost doubles the risk of developing this type of cancer. Furthermore, having a first-degree relative with ovarian cancer poses a minor risk for breast cancer $^{25}$.

Besides, health education plays its role in the importance of breast care and periodic selfexamination, given that it is important for early diagnosis of the disease, and sometimes cancer prevention.

\section{Leukaemia}

Leukaemia ranked second with regard to cancer cases in Syria during the studied period, with 5531 new cases $(11.9 \%$ of total recorded cancer cases). It was the second-highest cancer amongst females, with a total number of 2244 cases $(10.1 \%)$, and the same among males, with a total number of 3287 (13.6\%). This could be attributed to several factors, including:

- Prior chemotherapy raise the risk of having acute myeloid leukaemia (AML) in the future, usually within 3-5 years. Cytotoxic agents, which are commonly used in the 
treatment of different malignant diseases, are implicated with therapy-related AML ( $\mathrm{t}-$ AML), particularly alkylating agents and topoisomerase II inhibitors $30,31,32$.

- Viral causes such as hepatitis B virus lymphomas that appear after organ transplantation 9, 33. Besides, certain types of acute lymphocytic leukaemia could be associated with viral infections, like adult T-cell leukaemia-lymphoma (caused by the human Tlymphotropic virus type I (HTLV-I) and Burkitt lymphoma/leukaemia, which is related to Epstein- Barr virus (EBV) ${ }^{31,34}$, as well as acquired immune deficiency syndrome [AIDS] ${ }^{9,33}$.

- Exposure to radiation increase the risk of leukaemia cancer ${ }^{35,36,37,38}$. Radiation cause DNA mutations, deletions or translocations by stimulating double-strand splits into hematopoietic stem cells in a dose-dependent manner ${ }^{31}$.

- Concerning children under 15 years of age, leukaemia was the most common cancer throughout our study period. Childhood leukaemia could be associated with different conditions, such as:

- Several genetic conditions are associated with the development of childhood acute leukaemia such as down syndrome (10-20 fold increased likelihood) ${ }^{31,39,40,41,42,43}, \mathrm{Li}$ Fraumeni syndrome ${ }^{31,44,45}$ and inherited bone marrow failure syndromes (Fanconi anaemia, dyskeratosis congenital and Shwachman-Diamond syndrome) $31,40,41,43,46$.

- Fetus exposure to ionizing radiation could be carcinogenic, teratogenic or mutagenic. This is directly correlated with the exposure level and the stage of fetal development. The fetus is usually more sensitive to radiation throughout organogenesis (2-7 weeks after conception) and the early fetal period (8-15 weeks after conception) ${ }^{47,48}$.

\section{Lung Cancer}

Lung cancer ranked third in Syria, with a total number of cases about 4212 new cases $(9.1 \%$ of the overall reported cancer cases). It was the most common cancer among males with 3569 new cases $(14.7 \%)$. As for females, the number of new cases reached $643(2.9 \%)$.

Although cigarette smoking represents a major cause for lung cancer, significant numbers of lung cancer cases are reported among non-smokers. This can be explained by exposure to outdoor ambient air pollutants and other inhalable agents $49,50,51,52$.

Air pollution is one of the main causes of diseases in modern life. Air pollution levels increase because of emissions from different sources, such as industries, transportation, power generation and household burning. Most of the world population live in places where air pollution levels markedly exceed the WHO's health -based air- quality guidelines. Outdoor air pollution presents an urgent international health challenge because it is ubiquitous and poses many serious adverse effects for humans, including cancer ${ }^{52}$. Air pollutants contain sulfur dioxide, nitrogen dioxide, carbon monoxide, heavy metals and particulate matter ${ }^{49}, 52,53$. 
Studies indicate to a causal link between ambient air pollution (especially particulate matter in the surrounding air) with lung cancer incidence and mortality. Every year, hundreds of thousands of lung cancer deaths are attributed to particulate matter air pollution ${ }^{49,50,52,54}$.

\section{CONCLUSION}

We conclude that the incidence of various cancerous diseases does not exceed the standard rates conducted by WHO. Lung cancer had the highest incidence of cancer cases among males, while breast cancer had the highest ones among women and leukaemia was the most common among children. Concerning breast cancer, we recommend women, as much as possible, to maintain hormonalbalance (particularly oestrogen) and to stay away as much as possible from contraceptives related to high levels of the hormone in the body. Finally, we emphasize the need to provide the necessary support to protect the environment because of its negative impact on public health, including cancer, especially with regard to chemical and physical waste of a radiological nature.

\section{ACKNOWLEDGEMENT}

We thank Al-Bairouni University Hospital and the cancer control department in Damascus for their cooperation.

\section{REFERENCES}

1. Stephens FO, Aigner KR. What Is Malignancy?. In, Stephens FO, Aigner KR. Basics of Oncology. London: Springer; 2016; 3-16.

2. Khuda-Bukhsh AR, Samadder A, Saha SK. Introduction to cancer stem cells. In, Pathak S, Banerjee A. Cancer stem cells: New horizons in cancer therapies. Singapore: Springer Nature Singapore Pte Ltd; 2020; 1-14.

3. Loaiza B, Rojas E, Valverde M. The new model of carcinogenesis: The cancer stem cell hypothesis. In, Margarita Pesheva M, Dimitrov M, Stoycheva TS. Carcinogen. Croatia: InTech; 2012; 1-32.

4. Saeki H, Sugimachi K. Carcinogenic risk factors. JMAJ. 2001; 44(6): 245-249.

5. Pambuk CIA, Muhammad FM. Cancer cause: Biological, chemical and physical carcinogens. Merit Research Journal of Medicine and Medical Sciences. 2018; 6(9): 303-306.

6. Ljungman M. Physical Factors. In, Devita, VT, Lawrence TS, Rosenberg SA. Cancerprinciples \& practice of oncology. $11^{\text {th }}$ ed., USA: Wolters Kluwer; 2019; 297-310.

7. Ashley AK, Kemp CJ. Chemical Factors. In, Devita, VT, Lawrence TS, Rosenberg SA. Cancer- principles \& practice of oncology. $11^{\text {th }}$ ed., USA: Wolters Kluwer; 2019; 288296.

8. Soliman M. Cancer Causing Chemicals. In, Atroshi, F. Cancer causing substances. IntechOpen; 2018; 47-56. DOI: 10.5772/intechopen.71560. 
9. Buck CB, Ratner L, Tosato G. Oncogenic Viruses. In, Devita, VT, Lawrence TS, Rosenberg SA. Cancer- principles \& practice of oncology. $11^{\text {th }}$ ed., USA: Wolters Kluwer; 2019; 252-276.

10. IARC. Night shift work. IARC Monograph on the Identification of Carcinogenic Hazards to Humans. 2020; 124: 1-371.

11. Sung H, Ferlay J, Siegel RL, Laversanne M, Soerjomataram I, Jemal A, Bray F. Global cancer statistics 2020: GLOBOCAN estimates of incidence and mortality worldwide for 36 cancers in 185 countries. CA Cancer Journal for Clinicians. 2021; 0:1-41. DOI: 10.3322/caac. 21660 .

12. World Health Statistics 2020. Monitoring health for the SDGs. Geneva: World Health Organization; 2020; 1-92.

13. Wiebel FJ. Chemistry and primary toxicity of tobacco and tobacco smoke. In: Loddenkemper R, Kreuter M. The tobacco epidemic. $2^{\text {nd }}$ revised and extended ed., Switzerland: Karger; 2015; 37-46.

14. Yamaguchi NH. Smoking, immunity, and DNA damage. Transl Lung Cancer Res. 2019; 8(Suppl 1): S3-S6. DOI: 10.21037/tlcr.2019.03.02.

15. Talhout R, Schulz T, Florek E, van Benthem J, Wester P, Opperhuizen A. Hazardous compounds in tobacco smoke. International Journal of Environmental Research and Public Health. 2011; 8: 613-628. DOI:10.3390/ijerph8020613.

16. O’Connor RJ. Tobacco. In: Devita, VT, Lawrence TS, Rosenberg SA. Cancerprinciples \& practice of oncology. $11^{\text {th }}$ ed., USA: Wolters Kluwer; 2019; 238-252.

17. Munafo M, Drury M, Wakley G, Chambers R, Murphy M. Smoking and health. In, Munafo M, Drury M, Wakley G, Chambers R, Murphy M. Smoking cessation matters in primary care. UK: CRC Press; 2018; 19-35.

18. Christmann M, Kaina B. $\mathrm{O}^{6}$-methylguanine-DNA methyl transferase (MGMT): impact on cancer risk in response to tobacco smoke. Mutation Research. 2012; 736: 64- 74.

19. Travis RC, Key TJ. Oestrogen exposure and breast cancer risk. Breast Cancer Res. 2003; 5: 239-247. DOI: 10.1186/bcr628.

20. Yue W, Wang JP, Li Y, Fan P, Liu G, Zhang N, Conaway M, Wang H, Korach KS, Bocchinfuso W, Santen R. Effects of estrogen on breast cancer development: role of estrogen receptor independent mechanisms. Int J Cancer. 2010; 127(8): 1748-1757. DOI: $10.1002 / \mathrm{ijc} .25207$.

21. Stone SA, Han CJ, Senn, T, Korde LA, Allott K, Reding S, Whittington D. Sex hormones in women with elevated breast cancer risk undergoing weight loss. West $\mathbf{J}$ Nurs Res. 2019; 41(11); 1602-1622. DOI: 10.1177/0193945918820672.

22. Evans DGR, Lalloo F. Risk assessment and management of high risk familial breast 
cancer. J Med Genet. 2002; 39: 865-871.

23. Biro FM, Huang B, Wasserman H, Gordon CM, Pinney SM. Pubertal growth, IGF-1, and windows of susceptibility: Puberty and future breast cancer risk. Journal of Adolescent Health. 2021; 68(3): 517-522. DOI: 10.1016/j.jadohealth.2020.07.016.

24. Collaborative Group on Hormonal Factors in Breast Cancer. Menarche, menopause, and breast cancer risk: individual participant meta-analysis, including 118964 women with breast cancer from 117 epidemiological studies. Lancet Oncol. 2012; 13: 11411151.

25. Maisonneuve P. Epidemiology, lifestyle, and environmental factors. In, Veronesi U, Goldhirsch A, Veronesi P, Gentilini OD, Leonardi MC. Breast cancer- innovations in research and management. Switzerland: Springer International Publishing AG; 2017; 63-72.

26. Goldberg M, D’Aloisio AA, O’Brien KM, Zhao S, Sandler DP. Pubertal timing and breast cancer risk in the Sister Study cohort. Breast Cancer Research. 2020; 22: 112. DOI: $10.1186 / \mathrm{s} 13058-020-01326-2$.

27. Anstey EH, Shoemaker ML, Barrera CM, O’Neil ME, Ashley B. Verma AB, Holman DM. Breastfeeding and breast cancer risk reduction: Implications for black mothers. Am J Prev Med. 2017; 53(3 Suppl 1): S40-S46. DOI:10.1016/j.amepre.2017.04.024.

28. The National Institute for Health and Care Excellence (NICE). Familial breast cancer: Full Guideline Update of clinical guideline 14 and 41. Last updated November 2019; $1-253$.

29. Ellisen LW, Haber DA. Hereditary breast cancer. Annual Reviews in Medicine. 1998; 49: 425-436.

30. Cole AJ, Priddee NR, McAleer JJ. Chemotherapy causes cancer! A case report of therapy related acute myeloid leukaemia in early stage breast cancer. Ulster Med J. 2013; 82(2): 97-99.

31. Fiegl M. Epidemiology, pathogenesis, and etiology of acute leukemia. In, Hiddemann W. Handbook of acute leukemia. Switzerland: Springer International Publishing; 2016; 3-14.

32. Morton LM, Dores GM, Schonfeld SJ, Linet MS, Sigel BS, Lam CJK, Tucker MA, Curtis RE. Association of chemotherapy for solid tumors with development of therapyrelated myelodysplastic syndrome or acute myeloid leukemia in the Modern Era. JAMA Oncology. 2019; 5(3): 318-325. DOI: 10.1001/jamaoncol.2018.5625.

33. Pekarsky Y, Calin GA, Aqeilan R, Croce CM. Chronic lymphocytic leukemia: Molecular genetics and animal models. In, Caligaris-Cappio F, Dalla-Favera R. Chronic lymphocytic leukemia. Germany: Springer-Verlag Berlin Heidelberg; 2005; 
51-70.

34. Schiller JT, Lowy DR. An Introduction to virus infections and human cancer. In, Wu TC, Chang MH, Jeang KT. Viruses and human cancer - From basic science to clinical prevention. Switzerland: Springer Nature; 2021; 1-12.

35. Cardis E, Vrijheid M, Blettner M, Gilbert E, Hakama M, Hill C, Howe G, Kaldor J, Muirhead CR, Schubauer-Berigan M, Yoshimura T, Bermann F, Cowper G, Fix J, Hacker C, Heinmiller B, Marshall M, Thierry-Chef I, Utterback D, Ahn YO, Amoros E, Ashmore P, Auvinen A, Bae JM, Bernar J, Biau A, Combalot E, Deboodt P, Diez Sacristan A, Eklöf M, Engels H, Engholm G, Gulis G, Habib RR, Holan K, Hyvonen H, Kerekes A, Kurtinaitis J, Malker H, Martuzzi M, Mastauskas A, Monnet A, Moser M, Pearce MS, Richardson DB, Rodriguez-Artalejo F, Rogel A, Tardy H, TelleLamberton M, Turai I, Usel M, Veress K. The 15-Country collaborative study of cancer risk among radiationworkers in the nuclear industry: Estimates of radiation-related cancer risks. Radiation Research. 2007; 167: 396-416. DOI: 10.1667/RR0553.1.

36. Vrijheid M, Cardis E, Blettner M, Gilbert E, Hakama M, Hill C, Howe G, Kaldor J, Muirhead CR, Schubauer-Berigan M, YoshimuraT, Ahn YO, Ashmore P, Auvinen A, Bae JM, Engels H, Gulis G, Habib RR, Hosoda Y, Kurtinaitis J, Malker H, Moser M, Rodriguez-Artalejo F, Rogel A, Tardy A, Telle-Lamberton M, Turai I, Uselaa M, Veress K. The 15-country collaborative study of cancer risk among radiation workers in the nuclear industry: Design, Epidemiological methods and descriptive results. Radiation Research. 2007; 167: 361-379. DOI: 0033-7587/07.

37. Kuznetsova IS, Labutina EV, Hunter N. Radiation risks of leukemia, lymphoma and multiple myeloma incidence in the mayak cohort:1948-2004, PLoS ONE. 2016; 11(9): e0162710. DOI:10.1371/journal.pone.0162710.

38. Abalo KD, Rage E, Leuraud K, Richardson DB, Le Pointe HD, Laurier D, Bernier MO. Early life ionizing radiation exposure and cancer risks: systematic review and metaanalysis. Pediatric Radiology. 2021; 51: 45-56. DOI: 10.1007/s00247-020-04803-0.

39. Khan I, Malinge S, Crispino JD. Myeloid leukemia in down syndrome. Crit Rev Oncog. 2011; 16(1-2): 25-36.

40. Creutzig U, den Heuvel-Eibrink MM, Gibson B, Dworzak MN, Adachi S, de Bont E, Harbott J, Hasle H, Johnston D, Kinoshita A, Lehrnbecher T, Leverger G, Mejstrikova E, Meshinchi S, Pession A, Raimondi SC, Sung L, Stary J, Zwaan CM, Kaspers G. Diagnosis and management of acute myeloid leukemia in children and adolescents: recommendations from an international expert panel. Blood. 2012; 120 (16): 31873205.

41. Deepak V, Umashankar DN, Kumar RM. Common paediatric malignancies: A review. 
Journal of Indian Academy of Oral Medicine and Radiology. 2013; 25(2): 10. DOI:10.5005/jp-journals-10011.

42. Mateos MK, Barbaric D, Byatt SA, Sutton R, Marshall GM. Down syndrome and leukemia: insights into leukemogenesis and translational targets. Transl Pediatr. 2015; 4(2): 76-92.

43. Kaplan JA. Leukemia in children. Pediatrics in Review. 2019; 40(7): 319-331. DOI: 10.1542/pir.2018-0192.

44. Swaminathan M, Bannon SA, Routbort M, Naqvi K, Kadia TM, Takahashi K, Alvarado Y, Ravandi-Kashani F, Patel KP, Champlin R, Kantarjian H, Strong L, DiNardo CD. Hematologic malignancies and Li-Fraumeni syndrome. Cold Spring Harb Mol Case Stud. 2019; 5(1): a003210. DOI: 10.1101/mcs.a003210.

45. Winter G, Kirschner-Schwabe R, Groeneveld-Krentz S, Escherich G, Möricke A, von Stackelberg A, Stanulla M, Bailey S, Richter L, Steinemann D, Ripperger T, Escudero A, Farah R, Lohi O, Wadt K, Jongmans M, van Engelen N, Eckert C, Kratz CP. Clinical and genetic characteristics of children with acute lymphoblastic leukemia and $\mathrm{Li}-$ Fraumeni syndrome. Leukemia. 2021. DOI: 10.1038/s41375-021-01163-y

46. Alter BP. Diagnosis, Genetics, and management of inherited bone marrow failure syndromes. Hematology Am Soc Hematol Educ Program. 2007; 29-39. DOI: 10.1182/asheducation-2007.1.29.

47. Williams PM, Fletcher S. Health effects of prenatal radiation exposure. American Academy of Family Physicians. 2010; 82(5): 488-493.

48. Schüz J, Deltour I, Krestinina LY, Tsareva YV, Tolstykh EI, Sokolnikov ME, Akleyev AV. In utero exposure to radiation and haematological malignancies: pooled analysis of Southern Urals cohorts. British Journal of Cancer. 2017; 116: 126-133. DOI: 10.1038/bjc.2016.373.

49. Cohen AJ. Air pollution and lung cancer: what more do we need to know? Thorax. 2003; 58: 1010-1012.

50. Raaschou-Nielsen O, Andersen ZJ, Beelen R, Samoli E, Stafoggia M, Weinmayr G, Hoffmann B, Fischer P, Nieuwenhuijsen MJ, Brunekreef B, Xun WW, Katsouyanni K, Dimakopoulou K, Sommar J, Forsberg B, Modig L, Oudin A, Oftedal B, Schwarze PE, Nafstad P, De Faire U, L Pedersen NL, Östenson CG, Fratiglioni L, Penell J, Korek M, Pershagen G, Eriksen KT, Sørensen M, Tjønneland A, Ellermann T, Eeftens M, Peeters PH, Meliefste K, Wang M, Bueno-de-Mesquita B, Key TJ, de Hoogh K, Concin H, Nagel G, Vilier A, Grioni S, Krogh V, Tsai MY, Ricceri F, Sacerdote C, Galassi C, Migliore E, Ranzi A, Cesaroni G, Badaloni C, Francesco Forastiere F, Tamayo I, 51. Amiano P, Dorronsoro M, Trichopoulou A, Bamia C, Vineis P, Hoek G. Air pollution and 
lung cancer incidence in 17 European cohorts: Prospective analyses from the European Study of Cohorts for Air Pollution Effects (ESCAPE). Lancet Oncol. 2013; 14(9): 813-822. DOI: 10.1016/S1470-2045(13)70279-1.

52. Hardavella G, Sethi T. Epidemiology: Development and Perspectives. In, Dingemans AMC, Reck M, Westeel V. Lung Cancer, UK: European Respiratory Society; 2015; 111.

53. Turner MC, Andersen ZJ, Baccarelli A, Diver WR, Gapstur SM, Pope CA, Prada D, Samet J, Thurston G, Cohen A. Outdoor air pollution and cancer: An overview of the current evidence and public health recommendations. CA: A Cancer Journal for Clinicians. 2020; 70: 460-479. DOI: 10.3322/caac.21632.

54. Nyberg F, Gustavsson P, Järup L, Bellander T, Berglind N, Jakobsson R, Pershagen G, Urban air pollution and lung cancer in Stockholm. Epidemiology. 2000; 11: 487-495.

55. Shilpa N. Gowdaa SN, DeRoosc AJ, Huntd RP, Gassetta AJ, Mirabellie MC, et al. Ambient air pollution and lung cancer risk among never-smokers in the Women's Health Initiative. Environmental Epidemiology. 2019; 3: e076. DOI: 10.1097/EE9.0000000000000076.

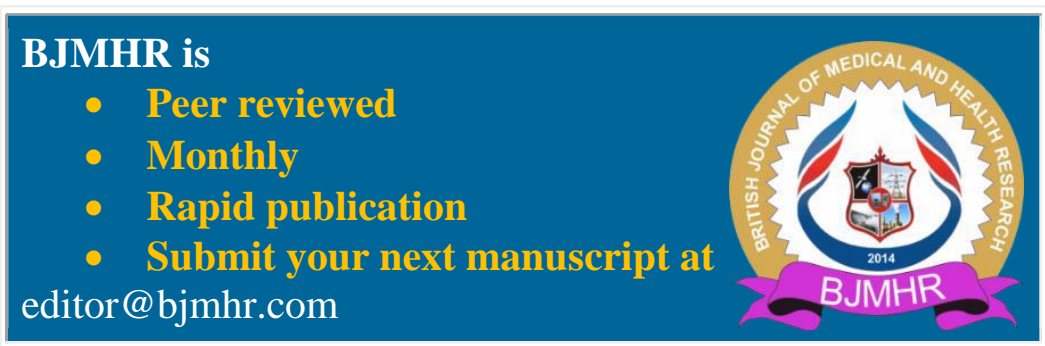

